УДК 378.046-021.68:616.716-089

DOI 10.11603/2311-9624.2020.1.12034

\author{
(В. О. Маланчук ${ }^{1}$, Я. А. Кульбашна ${ }^{1}$, Я. П. Нагірний ${ }^{2}$, С. М. Шувалов ${ }^{3}$ \\ Національний медичний університет імені О. О. Богомольця ${ }^{1}$ \\ Тернопільський національний медичний університет імені I. Я. Горбачевського МОЗ України ${ }^{2}$ \\ Вінницький національний медичний університет імені М. І. Пирогова ${ }^{3}$ \\ e-mail: j.kulbashna@gmail.com
}

\title{
Підготовка щелепно-лицевих хірургів в Україні: проект моделі
}

\section{ІНФОРМАЦІЯ}

Надійшла до редакції/Received: 03.02.2021 p.

Ключові слова: щелепно-лицева хірургія; спеціалізація; модель підготовки.

\section{АНОТАЦІЯ}

Резюме. У статті розкрито актуальність підготовки фахівців із щелепно-лицевої хірургії в Україні та упровадження фаху «Щелепнолицева хірургія». Обговорюються існуючі у світі моделі підготовки на базі як загальномедичної, так і стоматологічної освіти, яка в Україні забезпечує високий рівень компетентності з базових і загальномедичних дисциплін.

Мета дослідження - розробити проект моделі підготовки фахівців із фаху «Щелепно-лицева хірургія».

Результати досліджень та їх обговорення. Підготовка щелепнолицевих хірургів - це тривалий і відповідальний процес, який залежить як від особистісних якостей і компетентності лікаря, так і умов та спроможностей держави. На основі аналізу нормативних документів визначено спеціальності, поглиблені знання з яких необхідні для підготовки щелепно-лицевих хірургів, а також терміни 3 їх вивчення у рамках спеціалізації. Представлено проект моделі підготовки щелепно-лицевого хірурга на базі вищої медичної стоматологічної освіти кваліфікаційного рівня «лікар-стоматолог» і освітнього рівня «магістр стоматології (термін навчання 6 років і захист науково-дослідницької роботи), один рік інтернатури і двох років резидентури.

Висновки. В Україні існує нагальна потреба в упровадженні фаху «Щелепно-лицева хірургія» та підготовці лікарів відповідного профілю на основі розробленої моделі шляхом спеціалізації та резидентури на післядипломному етапі безперервного професійного розвитку.
Вступ. Складність фаху «Щелепно-лицева хірургія» (ЩЛХ) полягає в анатомо-фізіологічних особливостях органів і тканин, які входять у зону професійного інтересу, дотичності до сфер діяльності фахівців інших спеціальностей, локалізації життєво важливих органів і тканин, які забезпечують базові функції людського організму, оглядовості й соціальної значущості обличчя людини. Досягнення сучасної медицини та інноваційні технології оперативних втручань, зокрема: реконструктивно-відновлювальні операції після травматичних ушкоджень, видалення пухлин, запальні процеси із загрозливими для життя людини ускладненнями, трансплантація органів і тканин обличчя, вимагають як базових знань та умінь із загальної хірургії, трансплантології, нейрохірургії, оториноларингології, судинної хірургії, офтальмології та ін., так і високого рівня компетентності у стоматології. Тому підготовка щелепно-лицевих хірургів залишається актуальною, але і нині не вирішеною проблемою Україні.

Метою дослідження було розробити проект моделі підготовки фахівців із фаху «Щелепно-лицева хірургія».

Результати досліджень та їх обговорення. Підготовка щелепно-лицевих хірургів - це тривалий і відповідальний процес, який залежить як від особистісних якостей і компетентності лікаря, так і умов та спроможностей держави. у суспільстві десятиліттями триває дискусія про пріоритетність необхідної базової освіти -

ISSN 2311-9624. Клінічна стоматологія. 2021. № 1 
загальномедичної і стоматологічної. Нині існують дві основні моделі підготовки ЩЛХ:

- перша - на базі підготовки лікаря загальної практики 3 подальшою спеціалізацією терміном до 5 років із поглибленим вивченням стоматологічних дисциплін протягом не менше двох років;

- друга - типова для України - на базі стоматологічного факультету медичного ЗВо з подальшою інтернатурою та спеціалізацією за фахом «Хірургічна стоматологія» .

Аналіз міжнародного досвіду із проблеми дослідження засвідчив, що у багатьох зарубіжних країнах медичні школи випускають досить вузькопрофільних фахівців - дантистів, програма підготовки яких включає основи хірургічної стоматології, а ЩЛХ викладається лише оглядово. На противагу цьому - програма підготовки майбутніх стоматологів в Україні забезпечує грунтовну загальномедичну складову, яка практично не відрізняється від аналогічної на медичних факультетах. За останні десятиліття, на жаль, її обсяг дещо скоротився, проте у цілому залишається достатнім для глибокого розуміння фізіологічних і патологічних процесів в організмі людини. Необхідно зазначити що до часів такого невдалого реформування, випускники стоматологічних факультетів отримували військово-обліковий фах 6014 - «Загальний хірург» i лише другим - «Стоматолог».

Необхідно відзначити, що згідно із Законом про вищу освіту (3, стаття 60), поняття післядипломна освіта трактується як «спеціалізоване удосконалення освіти та професійної підготовки особи шляхом поглиблення, розширення та оновлення іï професійних знань, умінь та навичок або отримання іншої професії, спеціальності на основі здобутого раніше освітнього рівня та практичного досвіду. Послідовними етапами визначено інтернатуру на базі ступеня магістра медичного або фармацевтичного спрямування \{Пункт 3 частини третьої статті 61 в редакції Закону № 749-IX від 03.07.2020\} та резидентуру, в якій особа навчається виключно на відповідних клінічних кафедрах або базах резидентури $з$ метою отримання кваліфікації лікаря певної спеціальності відповідно до переліку спеціальностей резидентури $\{$ Пункт 4 частини третьої статті 61 із змінами, внесеними згідно із Законом № 2145-VIII від 05.09.2017\}.

Відповідно до Переліку назв циклів спеціалізації та удосконалення лікарів і провізорів у вищих медичних (фармацевтичному) закладах (факультетах) післядипломної освіти \{Із змінами, внесеними згідно з наказами Міністерства охорони здоров'я» (2) на сьогодні не передбачена спеціалізація лікарів щодо фаху ЩЛХ як не існує і самого фаху згідно з чинним наказом МОЗ щодо номенклатури лікарських спеціальностей (3), хоча в Україні існує не менше 15 кафедр відповідного профілю на базі стоматологічних факультетів медичних 3ВО і близько 40 профільних клінічних відділень регіонального рівня. У таблиці приведено порівняльну характеристику термінів спеціалізації з фахів, які вважаємо необхідними для підготовки ЩЛХ.

Таблищя. Порівняльна характеристика термінів спеціалізації

\begin{tabular}{|c|l|c|}
\hline Номер у переліку & \multicolumn{1}{|c|}{ Спеціальність } & Термін спеціалізації (міс.) \\
\hline 35 & Дитяча стоматологія & 3 \\
\hline 67 & Нейрохірургія & $3-5$ \\
\hline 73 & Онкохірургія & 10 \\
\hline 75 & Ортодонтія & 4 \\
\hline 76 & Ортопедична стоматологія & $3-5$ \\
\hline 78 & Оториноларингологія & 5 \\
\hline 79 & Офтальмологія & 3 \\
\hline 100 & Стоматологія & 3 \\
\hline 101 & Судинна хірургія & 2 \\
\hline 111 & Терапевтична стоматологія & 4 \\
\hline 114 & Торакальна хірургія & 4 \\
\hline 115 & Трансплантологія & 9 \\
\hline 123 & Хірургічна стоматологія & 4 \\
\hline 124 & Хірургія & \\
\hline 125 & Хірургія серця і магістральних судин & \\
\hline
\end{tabular}


Аналіз даних таблиці свідчить, що максимальний термін спеціалізації (10 міс.) відведений для тих фахів, які безпосередньо дотичні до підготовки ЩЛХ. Враховуючи вищезазначене, адекватна модель підготовки щлХ в Україні повинна враховувати базову стоматологічну освіту, на основі блоку базових і загальноклінічних дисциплін, який у цілому відповідає високому рівню загальномедичної підготовки і базуватись на концепції інтегративного поглиблення знань і умінь
3 таких розділів: «Хірургія» - 5 міс., «Онкохірургія» -2 міс., «Нейрохірургія» - 1 міс., «Торакальна хірургія» - 1 міс., «Хірургічна стоматологія» - 5 міс., «Оториноларингологія» - 1 міс., «Офтальмологія» - 1 міс., «Трансплантологія» - 2 міс, «Травматологія» - 2 міс., «Судинна хірургія» -2 міс, «Ортодонтія» -2 міс., усього -24 міс. Проект моделі підготовки щелепно-лицевого хірурга в Україні на основі нормативноправових актів України $(1,2,3)$ представлено на схемі.

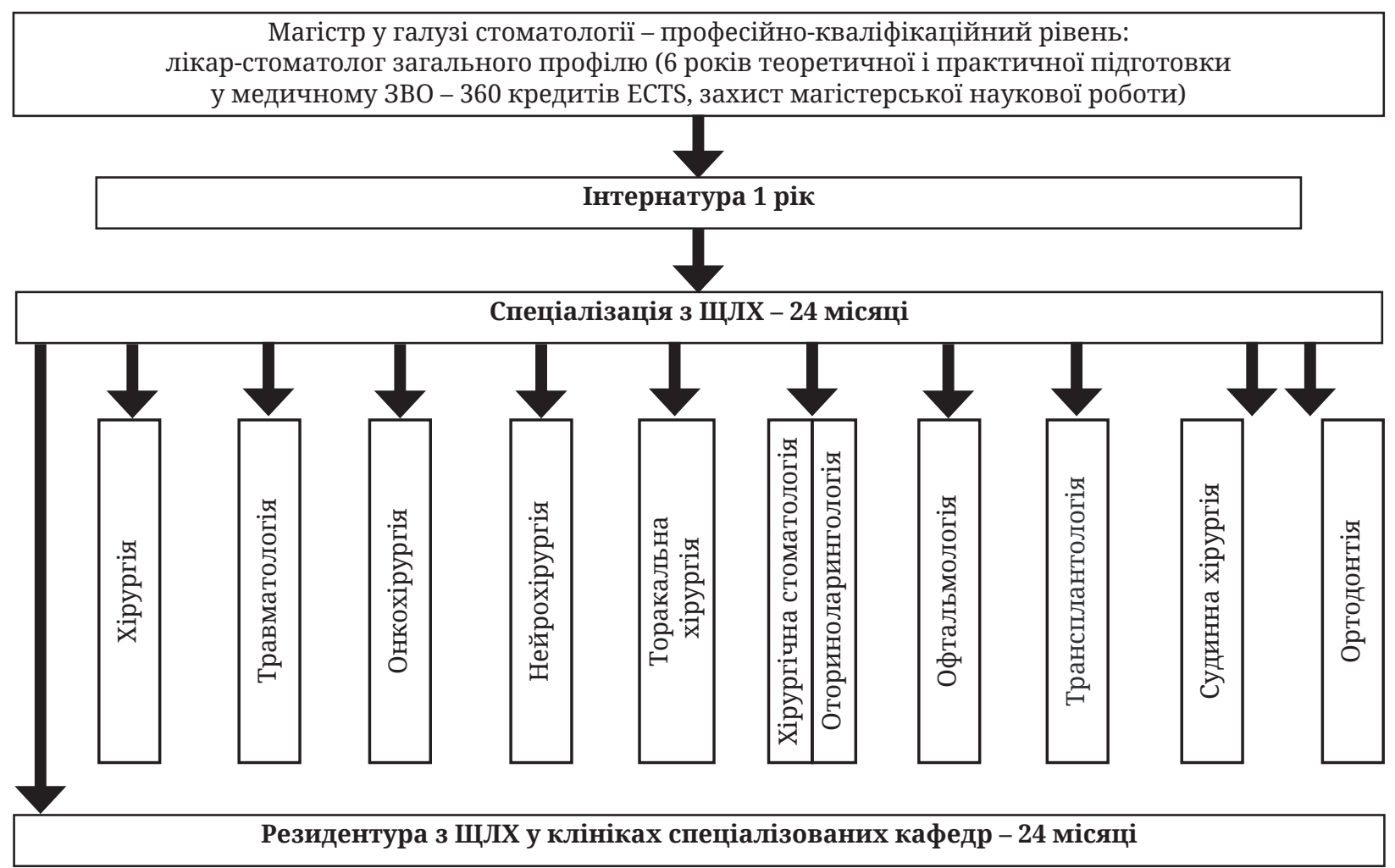

схема. Модель підготовки щелепно-лицевої хірургії в Україні.

Представлена модель при їі упровадженні забезпечить достатній рівень компетентності спеціалістів із фаху «Щелепно-лицева хірургія», науково-обгрунтований обсяг знань i умінь, економічну доцільність та раціональні терміни підготовки.
Висновки. В Україні існує нагальна потреба в упровадженні фаху «Щелепно-лицева хірургія» та підготовці лікарів відповідного профілю на основі розробленої моделі шляхом спеціалізації та резидентури на післядипломному етапі безперервного професійного розвитку.

\section{(․․ А. Маланчук ${ }^{1}$, Я. А. Кульбашна ${ }^{1}$, Я. П. Нагирный ${ }^{2}$, С. М. Шувалов ${ }^{3}$}

Национальный медицинский университет имени А. А. Богомольца ${ }^{1}$

Тернопольский национальный медицинский университет имени И. Я. Горбачевского МО3 Украины ${ }^{2}$ Винницкий национальный медицинский университет имени Н. И. Пирогова ${ }^{3}$

\section{Подготовка челюстно-лицевых хирургов: проект модели}

Резюме. В статье раскрыты актуальность подготовки специалистов челюстно-лицевой хирургии в Украине и внедрения специальности «Челюстно-лицевая хирургия». Обсуждаются существующие в 


\title{
Хірургічна стоматологія
}

мире модели подготовки на базе как общемедицинского, так и стоматологического образования, которое в Украине обеспечивает высокий уровень компетентности по базовым и общемедицинским дисциплинам.

Цель исследования - разработать проект модели подготовки специалистов по специальности «Челюстно-лицевая хирургия".

Результаты исследовний и их обсуждение. Подготовка челюстно-лицевых хирургов - это длительный и ответственный процесс, который зависит как от личностных качеств и компетентности врача, так и условий и возможностей государства. На основе анализа нормативных документов определены специальности, углубленные знания по которым необходимы для подготовки челюстнолицевых хирургов, а также сроки для их изучения в рамках специализации. Представлен проект модели подготовки челюстно-лицевого хирурга на базе высшего медицинского стоматологического образования квалификационного уровня «врач-стоматолог» и образовательного уровня «магистр стоматологии» (срок обучения 6 лет и защита научно-исследовательской работы), один год интернатуры и двух лет резидентуры.

Выводы. В Украине существует насущная необходимость во внедрении специальности «Челюстнолицевая хирургия» и в подготовке врачей соответствующего профиля на основе разработанной модели путем специализации и резидентуры на последипломном этапе непрерывного профессионального развития.

Ключевые слова: челюстно-лицевая хирургия; специализация; модель подготовки.

\author{
(C) . Malanchuk ${ }^{1}$, Ya. Kulbashna1, Ya. Nahirniy ${ }^{2}$, S. Shuvalov ${ }^{3}$ \\ O. Bohomolets National Medical University, Kyiv ${ }^{1}$ \\ I. Horbachevsky Ternopil National Medical University ${ }^{2}$ \\ M. Pyrohov Vinnytsia National Medical University ${ }^{3}$
}

\section{Training of maxillofacial surgeons in Ukraine: draft of the model}

Summary. The article reveals the relevance of training specialists in maxillofacial surgery in Ukraine and the introduction of the specialty "maxillofacial surgery". The existing models of training in the world are basing on general medical or dental education, which in Ukraine provides a high level of competence in basic and general medical disciplines.

The aim of the study - to develop a draft model of training specialists in the specialty "maxillofacial surgery". Results and Discussion. The training of maxillofacial surgeons is a long and responsible process, which depends on the personal qualities and competence of the doctor, as well as the conditions and capabilities of the state. Analysis of normative documents identified medical specialties, depth knowledge of which is necessary for the training of maxillofacial surgeons, defined terms, necessary for study in the specialization. In article presented the author 's draft of the maxillofacial surgeon training model on the basis of higher medical dental education of level qualification "dentist" and educational level - "master of dentistry" (term of study 6 years and defense of scientific work), one year of internship and two years of residency.

Conclusions. In Ukraine, there is an urgent need to introduce the specialty of "maxillofacial surgery" and train doctors of the relevant profile on the basis of the developed model through specialization and residency at the postgraduate stage of continuous professional development.

Key word: maxillofacial surgery; specialization; draft of the model.

\section{СПИСОК ЛІТЕРАТУРИ}

1. Про вищу освіту : Закон України // Урядовий кур’єр. - 2014. -13 серпня. - № 146. - С. 7-18.

2. Про затвердження Переліку назв циклів спеціалізації та вдосконалення лікарів і провізорів у вищих медичних (фармацевтичному) закладах (факультетах) післядипломної освіти : наказ Міністерства охорони здоров’я України https://zakon.rada.gov.ua/ rada/show/v0346282-98\#n12

3. Номенклатура лікарських спеціальностей : наказ Міністерства охорони здоров’я України https:// zakon.rada.gov.ua/laws/show/z0294-19\#Text 


\section{REFERENCES}

1. (2014). Zakon Ukrainy "Pro vyshchu osvitu» [Law of Ukraine "On Higher Education"]. Uriadovyi kurier Government Courier, 146, 7-18 [in Ukrainian].

2. Nakaz Ministerstva okhorony zdorovia Ukrainy «Pro zatverdzhennia Pereliku nazv tsykliv spetsializatsii ta vdoskonalennia likariv i provizoriv u vyshchykh medychnykh (farmatsevtychnomu) zakladakh (fakultetakh) pisliadyplomnoi osvity [Order of the Ministry of Health of Ukraine "On approval of the List of names of cycles of specialization and improvement of doctors and pharmacists in higher medical (pharmaceutical) institutions (faculties) of postgraduate education]. Retrieved from: https://zakon.rada.gov.ua/ rada/show/v0346282-98\#n12 [in Ukrainian].

3. Nakaz Ministerstva okhorony zdorovia Ukrainy «Nomenklatura likarskykh spetsialnostei» [Order of the Ministry of Health of Ukraine "Nomenclature of medicinal specialties"]. Retrieved from: https://zakon. rada.gov.ua/laws/show/z0294-19 [in Ukrainian]. 